\title{
Implementasi jaringan syaraf tiruan untuk menilai kelayakan tugas akhir mahasiswa (studi kasus di amik bukittinggi)
}

\author{
Novia Lestari ${ }^{1,}$ Lucky Lhaura Van FC $^{2}$ \\ ${ }^{1}$ Program Studi Manajemen Informatika AMIK Bukittinggi \\ ${ }^{2}$ Program Studi Teknik Informatika Universitas Lancang Kuning \\ Jl. Yos Sudarso KM. 8 Rumbai, Pekanbaru, Riau, telp. 08117532015 \\ Email: ${ }^{1}$ Novia_Lestarii@ rocketmail.com, ${ }^{2}$ Lucky@unilak.ac.id
}

\begin{abstract}
Abstrak
Masing-masing mahasiswa telah diberikan buku panduan penulisan tugas akhir untuk penyusunan tugas akhirnya. Namun masih ditemui beberapa perbedaan pada tugas akhir mahasiswa yang telah menyelesaikan tugas akhir tersebut. Sehingga, penilaian kelayakan tugas akhir perlu dilakukan guna memperoleh hasil yang baik dan sesuai dengan format yang ada, serta layak dipublikasikan sesuai kriteria atau ketentuan yang telah ditetapkan. Untuk mempercepat proses penilaian dan pengambilan keputusan apakah tugas akhir yang dinilai tersebut layak atau tidak, tim penilai terkadang hanya melihat hasil secara menyeluruh sebagai acuan, sehingga hasil penilaianpun tidak bisa dipastikan dengan benar dan tidak objektif. Penelitian ini akan mengimplementasikan jaringan syaraf tiruan menggunakan algoritma BackPropagation untuk menilai kelayakan tugas akhir mahasiswa dengan menggunakan software Matlab 6.1. Pengujian akan dilakukan dengan berbagai pola untuk membandingkan hasil dari jaringan syaraf tiruan tersebut, agar mendapatkan hasil penilaian yang optimal apakah tugas akhir yang dinilai tersebut layak atau tidak.
\end{abstract}

Kata Kunci : backpropagation, Jaringan Syaraf Tiruan, Keputusan, Tugas Akhir

\section{Abstract}

Each student has been given a guide book as the guidelines to their final assignment. But in fact, the students still face the difficulties in following the guidelines and finishing their final assignment. It caused their final assignment need to be evaluate based on the format. In increasing the assessment process on how effective and proper of the assignment, usually could be found through the final conclusion of their final assignment. It may caused some mistaken assessment in objectivity. This research will be implement the neural network by using BackPropagation Algorithm in order to know how effective it is, based on the final assignment of the college students through Matlab 6.1 Software. The assessment will use some methods in comparing of the neural network, to find the final conclusion about the reasonable of the research.

Keywords: Backpropagation, Decision, Final Assignment, Neural Network

\section{Pendahuluan}

Kemajuan teknologi komputer telah digunakan secara luas hampir disegala aspek bidang kehidupan manusia, diantaranya penerapan jaringan syaraf tiruan metode Backpropagation. Jaringan syaraf tiruan menjadi salah satu teknik yang banyak digunakan untuk masalah pengenalan karakter dan dianggap sebagai classifier yang kuat karena tingkat perhitungan dan keakuratannya yang tinggi [1]. Tingkat keberhasilan yang mencapai $80 \%$, membuat jaringan syaraf tiruan metode backpropagation sangat cocok digunakan untuk menangani berbagai kasus permasalahan, terutama masalah prediksi [2]. Jaringan saraf tiruan (JST) sebagai salah satu bagian 
dari Kecerdasaan Buatan (Artificial Intelligence) dalam ilmu komputer banyak digunakan untuk menyelesaikan permasalahan yang berhubungan dengan peramalan atau prediksi, terutama yang berbasis pada data time-series (history) [3].

Pada penelitian ini penulis akan membahas tentang salah satu kemajuan teknologi komputer dalam penerapan jaringan syaraf tiruan di bidang pendidikan yaitu untuk menilai kelayakan tugas akhir (TA) mahasiswa. Tugas akhir merupakan salah satu syarat bagi mahasiswa jenjang D3 untuk memperoleh gelar diploma. Dimana format penulisan dan penelitian yang tertuang pada tugas akhir harus sesuai dengan ketentuan akademik perguruan tinggi.

Begitu banyak dan beragamnya format tugas akhir yang diajukan mahasiswa, sehingga penilaian kelayakan tugas akhir perlu dilakukan guna memperoleh hasil yang baik dan sesuai dengan format yang ada, serta layak dipublikasikan sesuai kriteria atau ketentuan yang telah ditetapkan. Untuk mempercepat proses penilaian dan pengambilan keputusan apakah tugas akhir yang dinilai tersebut layak atau tidak, tim penilai terkadang hanya melihat hasil secara menyeluruh sebagai acuan, sehingga hasil penilaianpun tidak bisa dipastikan dengan benar dan tidak objektif.

Pada penelitian ini akan dikembangkan analisa Jaringan Syaraf Tiruan metode backpropagation untuk membantu penilaian kelayakan tugas akhir, sehingga diharapkan hasil yang dicapai melalui analisa ini akan memberikan keputusan yang lebih tepat, cepat dan optimal sebagai pertimbangan tim penilai dalam melakukan penilaian tugas akhir mahasiswa sebagai syarat memperoleh gelar diploma. Pertimbangan penggunaan jaringan syaraf tiruan karena kemampuannya dalam melakukan komputasi secara parallel dengan belajar dari polapola yang diajarkan[10].

\section{Tinjauan pustaka}

\section{Jaringan Syaraf Tiruan}

Jaringan saraf tiruan (artificial neural network) adalah sistem komputasi yang arsitektur dan operasinya diilhami dari pengetahuan tentang sel saraf biologis di dalam otak yang dapat digambarkan sebagai model matematis dan komputasi untuk fungsi aproksimasi non-linear, klasifikasi data cluster dan regresi non-parametrik atau sebuah simulasi dari koleksi model jaringan saraf biologi [4]. Sistem ini akan melakukan pembelajaran-pembelajaran yang bersifat derifatif untuk mencapai sebuah konvergensi (Rumehalrt). System syaraf tiruan adalah alat bantu yang digunakan secara umum dan diaplikasikan untuk memprediksi, mengklasifikasi dan Clustering. AI akan melakukan proses belajar sendiri berdasarkan data history yang telah didapat, kemudian berdasarkan itu akan dihasilkan experience data yang dipresentasikan pada decision Boundary untuk mencapai nilai keluaran [5]. Jaringan syaraf tiruan adalah model komputasi yang terinspirasi oleh sistem saraf pusat dan digunakan dalam berbagai variasi aplikasi. Sistem jaringan syaraf belajar dari berbagai pola masukan yang tersedia di dataset dan menyesuaikan koneksi bobot untuk mencapai hasil yang diharapkan [6].

\subsection{Algoritma Backpropagation}

Backpropagation adalah metode penurunan gradien untuk meminimalkan kuadrat error keluaran. Ada tiga tahap yang harus dilakukan dalam pelatihan jaringan, yaitu tahap perambatan maju (forward propagation), tahap perambatan balik (backpropagation), dan tahap perubahan bobot dan bias [7]. Jaringan backpropagation merupakan salah satu algoritma yang sering digunakan dalam menyelesaikan masalah-masalah yang rumit. Algoritma ini memiliki dasar matematis yang kuat dan dilatih dengan menggunakan metode belajar terbimbing. Jaringan backpropagation terdiri dari atas tiga lapisan atau lebih unit pengolahan, yaitu lapisan masukan (input) terdiri dari atas variabel masukan unit sel saraf, lapisan tersembunyi dan lapisan keluaran (output). Neural network dengan metode backpropagation ini memiliki tahapan pengenalan terhadap jaringan multilayer, yaitu [8] : 
1. Nilai dikirim melalui input layer ke hidden layer (forward) sampai ke output layer (actual output)

2. Actual output dibandingkan dengan output yang diharapkan jika ada perbedaan maka dinyatakan sebagai error.

3. Selanjutnya error dikirim secara backward mulai dari output layer ke hidden layer kemudian diteruskan ke input layer.

Langkah-langkah pelatihan dengan Algoritma BackPropagation adalah sebagai berikut : [9]

0 . Inisialisasi

1. Selama kondisi berhenti bernilai salah, kerjakan langkah 2-9

2. Untuk setiap data pelatihan (training data), lakukan langkah 3-8

Umpan maju (feed forward)

3. Setiap unit input $X_{\mathrm{i}}, \mathrm{i}=1, \ldots \ldots, \mathrm{n}$ menerima sinyal input dan menyebarkan sinyal input ke seluruh unit-unit lapisan tersembunyi

4. Masing - masing unit di lapisan tersembunyi dikalikan dengan faktor penimbang (bobot) dan dijumlahkan serta ditambah dengan biasnya.

(1)

$$
z_{-} n e t_{j}=v_{j 0}+\sum_{i=1}^{n} x_{i} v_{j i} \text {, }
$$

Di mana,$v_{j 0}=$ bias pada unit tersembunyi $\mathrm{j}$ aplikasikan fungsi aktivasinya untuk menghitung sinyal keluarannya. Setelah itu hitung keluaran sesuai dengan fungsi aktivasi yang digunakan $z_{j}=f\left(z_{\_} n e t_{j}\right)$, jika fungsi aktivasi yang dipakai adalah sigmoid biner maka hasil keluaran dari lapisan tersembunyi menjadi

$$
z_{j}=f\left(z_{-} n e t_{j}\right)=\frac{1}{1+\varepsilon^{-z_{-n a t} t_{j}}},
$$

kemudian mengirim sinyal keluaran tersebut ke unit - unit keluaran.

5. Tiap-tiap output $\left(x_{k}, k=1, \ldots, \mathrm{m}\right)$ menjumlahkan bobot sinyal input

$$
y_{-} n e t_{k}=w_{k 0}+\sum_{j=1}^{p} z_{j} w_{k j} \text {, }
$$

Di mana $w k_{0}=$ bias pada unit keluaran $\mathrm{k}$ dan aplikasikan fungsi aktivasinya untuk menghitung sinyal keluarannya. Setelah itu hitung keluaran sesuai dengan fungsi aktivasi yang digunakan $y_{k}=f\left(y_{-} n e t_{k}\right)$, jika fungsi aktivasi yang dipakai adalah sigmoid biner maka hasil keluaran dari lapisan tersembunyi menjadi

$$
y_{k} \quad=\quad f\left(y \_n e t_{k}\right)=
$$

Umpan mundur / propagasi error

6. Setiap unit output $\left(y_{k}, k=1, \ldots, \mathrm{m}\right)$ menerima pola target sesuai dengan pola input pelatihan, untuk menghitung kesalahan (error) antara target dengan output yang dihasilkan jaringan

(5)

$$
\delta_{k}=\left(t_{k}-y_{k}\right) f^{\prime}\left(y_{-} n e t_{k}\right)=\left(t_{k}-y_{k}\right) y_{k}\left(1-y_{k}\right),
$$

Di mana $\delta_{\mathrm{k}}$ merupakan unit kesalahan yang akan dipakai dalam perubahan bobot layar di bawahnya (langkah 7). Hitung suku perubahan bobot $\mathrm{w}_{\mathrm{kj}}$ (yang akan dipakai nanti untuk merubah bobot $\mathrm{w}_{\mathrm{kj}}$ ) dengan laju percepatan $\alpha$. Dengan rumus :

(6)

$$
\Delta w_{k j}=\alpha \delta_{k} z_{j},
$$

7. Hitung faktor $\delta$ unit tersembunyi berdasarkan kesalahan di setiap unit tersembunyi $\mathrm{z}_{\mathrm{j}}(\mathrm{j}$ $=1,2, \ldots, p)$ dengan rumus :

$$
\delta \_n e t_{j}=\sum_{k=1}^{m} \delta_{k} w_{k j} \text {, }
$$

Faktor $\delta$ unit tersembunyi : 


$$
\delta_{j}=\delta \_n e t_{j} f\left(z \_n e t_{j}\right)=\delta \__{n} t_{j} z_{j}\left(1-z_{j}\right)
$$

(8)

Hitung suku perubahan bobot $v_{j i}$ (yang akan dipakai nanti untuk merubah bobot $v_{j i}$ ) dengan rumus :

$$
\Delta v_{j i}=\alpha \delta_{j} x_{i},
$$

update bobot dan bias

8. Hitung semua perubahan bobot dengan cara :

Perubahan bobot garis yang menuju ke unit keluaran dengan menggunakan rumus :

$$
W_{j k}(\text { baru })=W_{j k}(\text { lama })+\Delta W_{j k}
$$

di mana $(\mathrm{k}=1,2, \ldots, \mathrm{m} ; \mathrm{j}=0,1, \mathrm{p})$. Perubahan bobot garis yang menuju ke unit tersembunyi yaitu dengan menggunakan rumus:

$$
v_{j i}(\text { baru })=v_{j i}(\text { lama })+\Delta v_{j i}
$$

di mana $(j=1,2, . ., p ; i=0,1, \ldots, n)$. Demikian juga untuk setiap unit tersembunyi mulai dari unit ke-1 sampai dengan unit ke-p dilakukan peng-update-tan bias :

$$
v_{o j}(\text { baru })=v_{o j}(\text { lama })+\Delta v_{o j}
$$

9. Uji kondisi berhenti (akhir iterasi )

Jika kondisi berhenti terpenuhi, maka pelatihan jaringan dapat dihentikan.

Setelah proses pelatihan selesai, nilai-nilai yang didapat dari output jaringan (hasil peramalan Jaringan Syaraf Tiruan) harus dikembalikan (denormalisasi) ke nilai aslinya dengan persamaan sebagai berikut:

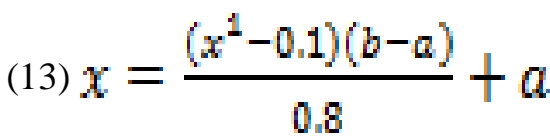

Kesalahan pada keluaran dari jaringan merupakan selisih antara keluaran aktual (current output) dan keluaran target (desired output). Langkah berikutnya adalah menghitung nilai MAPE (Mean Absolute Percentage Error) yang merupakan hasil pengurangan nilai rata-rata target dengan nilai output hasil pelatihan pada lapisan output tiap data.

Nilai MAPE dapat dihitung menggunakan rumus berikut :

$M A P E=\frac{1}{n} \sum \frac{y t-y t}{y t} \times 100 \%$

$$
\text { (14) }
$$

Di mana,

$$
\begin{aligned}
& y t=\text { nilai target } \\
& y^{\prime} t=\text { nilai actual output } \\
& n=\text { jumlah data }
\end{aligned}
$$

\section{Metode penelitian}

Dalam hal ini metode penelitian yang digunakan adalah kualitatif, yaitu membandingkan teori-teori yang ada dengan permasalahan yang terjadi di perusahaan dan kemudian mengadakan pembahasan terhadap masalah yang ada berdasarkan teori-teori tersebut. Dalam pengumpulan data dan informasi untuk penulisan penelitian ini dilakukan dengan beberapa cara yaitu:

1. Penelitian Lapangan (Field Research)

Dimana penulis turun langsung mengambil data yang diperlukan guna menyelesaikan penelitian ini, seperti mengadakan wawancara dengan pihak yang berkepentingan dan memperoleh data di perusahaan tersebut. 


\section{Penelitian Pustaka (Library Research)}

Dengan membaca dan mempelajari literatur-literatur yang berhubungan dengan permasalahan yang sedang diteliti.

3. Penelitian Laboratorium (Laboratorium Reseach)

Penelitian yang dilakukan di laboratorium komputer dalam pengujian penilaian kelayakan tugas akhir.

Agar penelitian ini terarah, maka diperlukan kerangka penelitian seperti yang tergambar pada Gambar 1 di bawah ini :

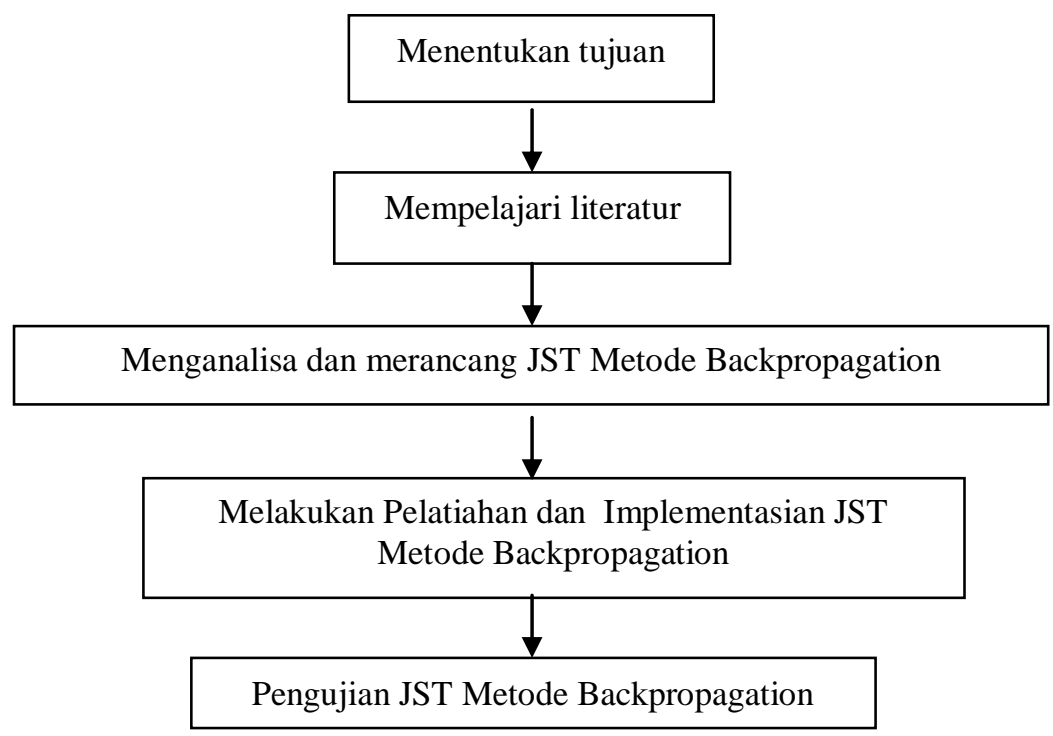

Gambar 1. Kerangka Kerja Penelitian

1. Merumuskan Masalah

Merumuskan masalah merupakan langkah untuk menemukan berbagai masalah yang terdapat pada sistem yang lama. Pada tahap ini dilakukan peninjauan sistem yang akan diteliti dan menggali permasalahan yang ada pada sistem yang berjalan pada saat ini.

\section{Menentuan Tujuan}

Setelah masalah dirumumuskan, sehingga kita dapat menentukan tujuan yang berguna untuk memperjelas kerangka tentang apa yang menjadi sasaran dari penelitian ini. Pada tahap ini ditentukan tujuan dari penelitian ini adalah bagaimana menilai kelayakan tugas akhir (TA) mahasiswa.

\section{Mempelajari Literatur}

Tahap ini dilakukan dengan tujuan untuk mencari informasi mengenai metode apa yang akan digunakan untuk menyelesaikan permasalahan yang akan diteliti, serta mendapatkan dasar referensi yang kuat bagi peneliti dalam menerapkan suatu metode yang digunakannya.

\section{Menganalisa dan Merancang Sistem}

Tahapan analisa sistem dilakukan dengan tujuan untuk memahami kerja dari sistem yang ada dan menemukan kelemahan-kelemahan sistem serta dapat mengidentifikasikan kebutuhan dalam merancang JST. Dari hasil analisa didapatkan beberapa langkah yang harus dilakukan dalam merancang JST sebagai berikut : 
a. Pembagian Data

Proses pembagian data dilakukan untuk membagi data menjadi dua bagian. Data - data penilaian kelayakan tugas akhir (TA) mahasiswa dibagi dua sebagai data pelatihan dan data pengujian.

b. Preprocessing / Normalisasi

Sebelum digunakan untuk proses pelatihan, perlu dilakukan transformasi terhadap nilai input dan target sehingga data-data input dan target tersebut masuk dalam suatu range tertentu.

c. Perancangan struktur jaringan yang optimum

Pada proses perancangan struktur jaringan yang optimum ini, akan ditentukan jumlah input layer, hidden layer, dan output layer yang akan digunakan dalam jaringan. Jaringan syaraf tiruan ini akan dirancang dengan menggunakan 7 buah input, dimana input tersebut berdasarkan kriteria penilaian kelayakan tugas akhir (TA) mahasiswa yaitu : abstrak, pendahuluan, landasan teori, metode penelitian, hasil dan pembahasan, penutup dan daftar pustaka. Sedangkan yang akan menjadi output berupa nilai layak atau tidak layak.

d. Menentukan laju pembelajaran (learning rate) dan Momentum

Hasil keputusan yang kurang memuaskan dapat diperbaiki dengan penggunaan koefisien pemahaman dan momentum secara trial and error untuk mendapatkan nilai bobot yang paling optimum agar MSE jaringan dapat diperbaiki.

e. Postprocessing / Denormalisasi

Setelah proses pelatihan selesai, nilai-nilai ternormalisasi output jaringan harus dikembalikan (denormalisasi) ke nilai aslinya untuk mendapatkan nilai output pada range yang sebenarnya. Setelah proses perancangan JST selesai maka JST siap untuk diimplementasikan ke program Matlab 6.1.

5. Melakukan Pelatihan dan Implemenasi JST

Pada tahap ini JST akan dilatih dengan menggunakan data pelatihan yang diperoleh dari data-data penilaian kelayakan tugas akhir (TA) mahasiswa pada periode sebelumnya . JST akan terus dilatih sampai menghasilkan output yang diharapakan dengan nilai error yang minimum. Pelatihan dilakukan dengan menggunakan dua tahapan.

Tahapan - tahapan yang digunakan dalam pelatihan yaitu :

1. Pelatihan secara manual

Pelatihan secara manual dilakukan dengan mengolah data yang telah didapatkan dari proses analisa manual.

2. Kemudian data tersebut di masukkan ke dalam rumus - rumus pelatihan algoritma backpropagation pada bab 1 .

\section{Menguji JST}

Tahap berikutnya adalah pengujian system. Pengujian sistem ini dilakukan dengan tujuan untuk mengetahui sistem yang dibangun berjalan dengan baik atau tidak dengan melihat batasan dan kriteria tertentu. Pada tahap ini akan dilakukan pelatihan terhadap jaringan untuk mengenal pola dan bisa mencapai target yang diinginkan. Setelah mencapai target dan mengenali pola, maka akan dilakukan pengujian dengan menggunakan software matlab 6.1.

\section{Hasil dan Pembahasan}

\subsection{Analisa Data Jaringan Syaraf Tiruan}

Analisa Data ini akan diproses dengan Jaringan Saraf Tiruan dengan metode backpropagation dan akan menghasilkan informasi yang akan dibutuhkan. Data tugas akhir mahasiswa ditentukan berdasarkan kriteria yang menjadi tujuan dalam pengambilan keputusan pada penilaian dengan menggunakan Jaringan Syaraf Tiruan. Analisa data akan dikelompokkan ke dalam 7 kriteria yaitu seperti yang terlihat pada Tabel 1 berikut : 
Tabel 1 Tabel Kriteria Penilaian Penelitian Tindakan Kelas Guru

\begin{tabular}{|l|l|l|}
\hline No & \multicolumn{2}{|c|}{ Kriteria } \\
\hline 1 & $\mathrm{x} 1$ & Abstrak \\
\hline 2 & $\mathrm{x} 2$ & Pendahuluan \\
\hline 3 & $\mathrm{x} 3$ & Landasan Teori \\
\hline 4 & $\mathrm{x} 4$ & Metode Penelitian \\
\hline 5 & $\mathrm{x} 5$ & Hasil dan Pembahasan \\
\hline 6 & $\mathrm{x} 6$ & Penutup \\
\hline 7 & $\mathrm{x} 7$ & Daftar Pustaka \\
\hline
\end{tabular}

\subsection{Skenario Pengujian}

Pengujian dapat dilakukan setelah melakukan pelatihan terhadap data yang ada. Dalam melakukan pengujian data dibutuhkan alat bantu yaitu Software yang akan digunakan dalam pengujian data dengan Jaringan Saraf Tiruan untuk penilaian kelayakan tugas akhir mahasiswa tersebut yaitu dengan menggunakan software Matlab 6. Data yang akan diolah menggunakan Matlab terlebih dahulu dinormalisasikan seperti yang terlihat pada Tabel 2 dan 3 berikut ini :

Tabel 2 Data Normalisasi Pelatihan

\begin{tabular}{|c|c|c|c|c|c|c|c|c|}
\hline $\mathbf{p}$ & $\mathbf{x 1}$ & $\mathbf{x 2}$ & $\mathbf{x 3}$ & $\mathbf{x 4}$ & $\mathbf{x 5}$ & $\mathbf{x 6}$ & $\mathbf{x 7}$ & $\mathbf{t}$ \\
\hline p1 & 0,3 & 0,7 & 0,3 & 0,7 & 0,7 & 0,7 & 0,3 & 1 \\
\hline p2 & 0,7 & 0,7 & 0,7 & 0,7 & 0,9 & 0,7 & 0,7 & 1 \\
\hline p3 & 0,3 & 0,7 & 0,3 & 0,7 & 0,7 & 0,7 & 0,3 & 1 \\
\hline p4 & 0,7 & 0,7 & 0,7 & 0,7 & 0,7 & 0,7 & 0,7 & 1 \\
\hline p5 & 0,3 & 0,7 & 0,7 & 0,9 & 0,7 & 0,7 & 0,7 & 1 \\
\hline p6 & 0,3 & 0,7 & 0,7 & 0,7 & 0,7 & 0,7 & 0,7 & 1 \\
\hline p7 & 0,3 & 0,3 & 0,3 & 0,7 & 0,7 & 0,7 & 0,3 & 0 \\
\hline p8 & 0,7 & 0,3 & 0,7 & 0,7 & 0,7 & 0,7 & 0,3 & 1 \\
\hline p9 & 0,3 & 0,3 & 0,3 & 0,7 & 0,3 & 0,3 & 0,3 & 0 \\
\hline p10 & 0,1 & 0,3 & 0,3 & 0,7 & 0,3 & 0,3 & 0,3 & 0 \\
\hline p11 & 0,3 & 0,3 & 0,7 & 0,7 & 0,7 & 0,7 & 0,7 & 1 \\
\hline p12 & 0,7 & 0,9 & 0,7 & 0,9 & 0,9 & 0,7 & 0,7 & 1 \\
\hline p13 & 0,7 & 0,9 & 0,7 & 0,9 & 0,9 & 0,7 & 0,7 & 1 \\
\hline p14 & 0,3 & 0,3 & 0,7 & 0,7 & 0,7 & 0,7 & 0,3 & 1 \\
\hline p15 & 0,7 & 0,9 & 0,7 & 0,7 & 0,7 & 0,9 & 0,7 & 1 \\
\hline p16 & 0,3 & 0,7 & 0,9 & 0,7 & 0,9 & 0,7 & 0,3 & 1 \\
\hline
\end{tabular}

Tabel 3 Data Normalisasi Pengujian

\begin{tabular}{|c|c|c|c|c|c|c|c|c|}
\hline p & $\mathbf{x 1}$ & $\mathbf{x 2}$ & $\mathbf{x 3}$ & $\mathbf{x 4}$ & $\mathbf{x 5}$ & $\mathbf{x 6}$ & $\mathbf{x 7}$ & $\mathbf{t}$ \\
\hline p36 & 0,7 & 0,7 & 0,7 & 0,7 & 0,9 & 0,7 & 0,7 & 1 \\
\hline p37 & 0,3 & 0,7 & 0,3 & 0,7 & 0,7 & 0,7 & 0,7 & 1 \\
\hline p38 & 0,3 & 0,3 & 0,3 & 0,7 & 0,7 & 0,3 & 0,3 & 0 \\
\hline p39 & 0,7 & 0,7 & 0,7 & 0,9 & 0,7 & 0,7 & 0,7 & 1 \\
\hline p40 & 0,3 & 0,7 & 0,3 & 0,7 & 0,7 & 0,7 & 0,7 & 1 \\
\hline
\end{tabular}




\begin{tabular}{|c|c|c|c|c|c|c|c|c|}
$\mathrm{p} 41$ & 0,7 & 0,3 & 0,7 & 0,7 & 0,7 & 0,7 & 0,3 & 1 \\
\hline $\mathrm{p} 42$ & 0,7 & 0,7 & 0,7 & 0,7 & 0,9 & 0,7 & 0,7 & 1 \\
\hline $\mathrm{p} 43$ & 0,3 & 0,7 & 0,7 & 0,7 & 0,7 & 0,7 & 0,3 & 1 \\
\hline $\mathrm{p} 44$ & 0,3 & 0,3 & 0,3 & 0,7 & 0,7 & 0,7 & 0,3 & 0 \\
\hline $\mathrm{p} 45$ & 0,3 & 0,7 & 0,7 & 0,7 & 0,7 & 0,7 & 0,7 & 1 \\
\hline $\mathrm{p} 46$ & 0,3 & 0,7 & 0,3 & 0,7 & 0,3 & 0,3 & 0,3 & 0 \\
\hline $\mathrm{p} 47$ & 0,3 & 0,7 & 0,3 & 0,7 & 0,3 & 0,7 & 0,3 & 0 \\
\hline $\mathrm{p} 48$ & 0,7 & 0,7 & 0,7 & 0,7 & 0,9 & 0,7 & 0,7 & 1 \\
\hline $\mathrm{p} 49$ & 0,3 & 0,7 & 0,7 & 0,7 & 0,3 & 0,7 & 0,7 & 1 \\
\hline $\mathrm{p} 50$ & 0,3 & 0,7 & 0,7 & 0,7 & 0,7 & 0,7 & 0,3 & 1 \\
\hline
\end{tabular}

Tabel 2 dan tabel 3 menunjukkan data pelatihan dan pengujian yang sudah dinormalisasikan. Data real yang digunakan harus dinormalisasikan terlebih dahulu dalam bentuk sigmoid biner bernilai antara 0 dan 1 . Dimana layak $=1$ dan tidak layak $=0$.

\subsection{Pelatihan Secara Software}

a. Pola 1

- Jumlah neuron pada input layer sebanyak 7 neuron.

- Jumlah neuron pada hidden layer sebanyak 4 neuron.

- Toleransi error sebesar 0.01

- Learning rate sebesar 0.1

- Momentum sebesar 0.7

- Max epoch sebanyak 100.000 epoch

Pada proses pelatihan secara manual, didapatkan hasil berupa output dan juga error. Proses pelatihan dengan mengunakan syntax pada matlab yaitu dengan : net=train(net,pn,tn). Grafik dari Jaringan Syaraf Tiruan pola 1 dapat dilihat pada Gambar 1 berikut :

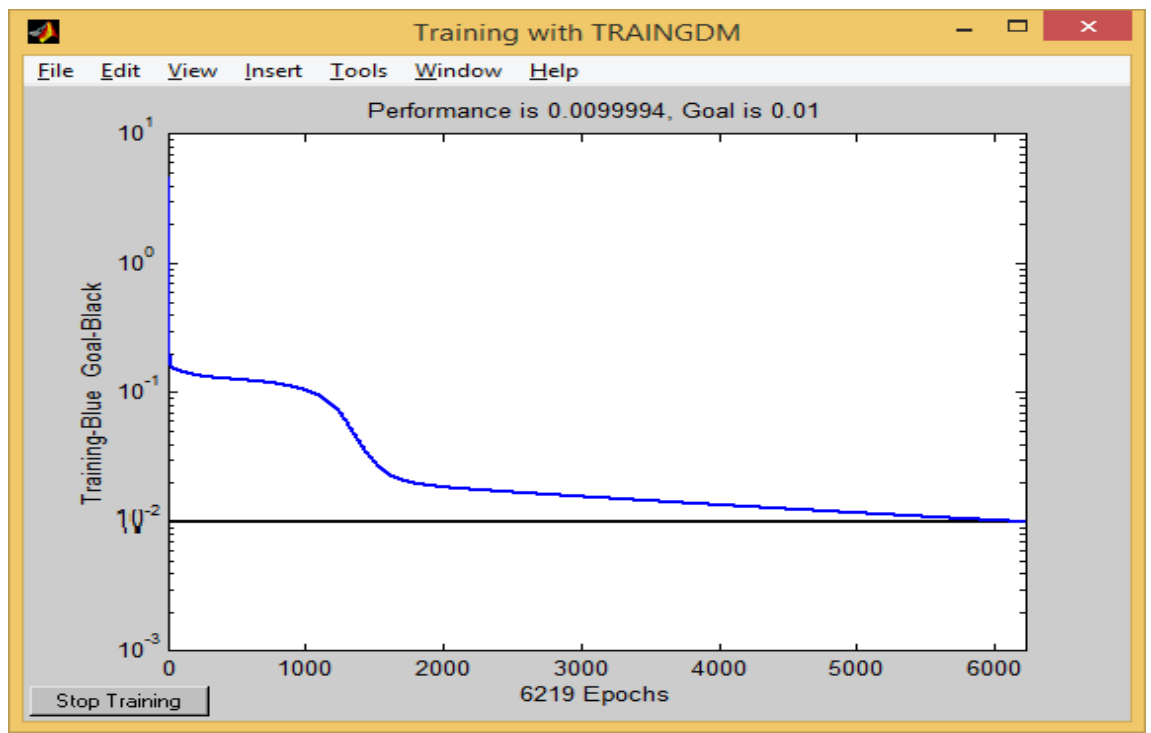

Gambar 1 Pelatihan Model Arsitektur 7-4-1 Mencapai Goal 
Dari gambar di atas dapat dilihat bahwa goal akan tercapai pada jumlah epoch ke 6219 dengan nilai error 0,0099994. Pelatihan ini menggunakan Jaringan Saraf Tiruan dengan metode backpropagation dan mempunyai model arsitektur jaringan 7-4-1.

Hasil dari pengujian Jaringan Saraf Tiruan setelah pelatihan dengan target error yang diinginkan adalah 0,01 dapat terlihat pada Tabel 4 di bawah ini :

Tabel 4 Hasil Pelatihan Jaringan Saraf Tiruan Dengan Model 7-4-1

b. Pola 2

\begin{tabular}{|c|c|c|c|}
\hline $\mathbf{P}$ & Target & Hasil & Error \\
\hline p1 & 1 & 0.8776 & 0.1224 \\
\hline p2 & 1 & 1.0653 & -0.0653 \\
\hline p3 & 1 & 0.8776 & 0.1224 \\
\hline p4 & 1 & 1.0096 & -0.0096 \\
\hline p5 & 1 & 1.0319 & -0.0319 \\
\hline p6 & 1 & 1.0035 & -0.0035 \\
\hline p7 & 0 & 0.1910 & -0.1910 \\
\hline p8 & 1 & 1.0493 & -0.0493 \\
\hline p9 & 0 & -0.0281 & 0.0281 \\
\hline p10 & 0 & -0.0281 & 0.0281 \\
\hline p11 & 1 & 0.8928 & 0.1072 \\
\hline p12 & 1 & 1.0370 & -0.0370 \\
\hline P13 & 1 & 1.0370 & -0.0370 \\
\hline P14 & 1 & 0.9603 & 0.0397 \\
\hline P15 & 1 & 0.9852 & 0.0148 \\
\hline
\end{tabular}

- Jumlah neuron pada input layer sebanyak 7 neuron.

- Jumlah neuron pada hidden layer sebanyak 5 neuron.

- Toleransi error sebesar 0.01

- Learning rate sebesar 0.1

- Momentum sebesar 0.7

- Max epoch sebanyak 100.000 epoch

Pada proses pelatihan secara manual, didapatkan hasil berupa output dan juga error. Proses pelatihan dengan mengunakan syntax pada matlab yaitu dengan : net=train $(n e t, p n, t n)$. Grafik dari Jaringan Syaraf Tiruan pola 2 dapat dilihat pada Gambar 2 berikut :

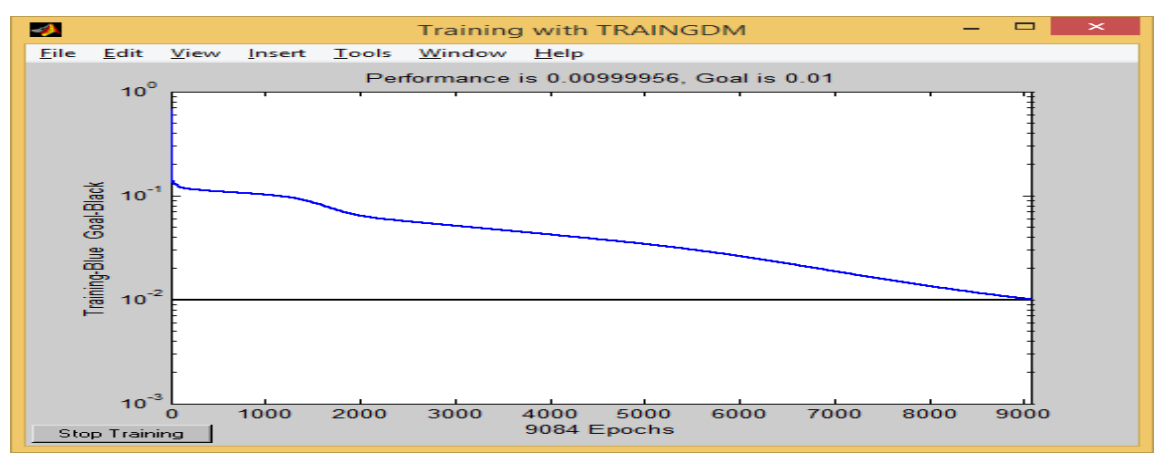

Gambar 2. Pelatihan Model Arsitektur 7-8-1 Mencapai Goal 
Dari gambar di atas dapat dilihat bahwa goal akan tercapai pada jumlah epoch ke 9084 dengan nilai error 0,00999956. Hasil dari pengujian Jaringan Saraf Tiruan setelah pelatihan dengan target error yang diinginkan adalah 0,01 dapat terlihat pada Tabel 5 di bawah ini :

Tabel 5 Hasil Pelatihan Jaringan Saraf Tiruan Dengan Model 7-5-1

\begin{tabular}{|c|c|c|c|}
\hline $\mathbf{P}$ & Target & Hasil & Error \\
\hline p1 & 1 & 0.9586 & 0.0414 \\
\hline p2 & 1 & 1.0150 & -0.0150 \\
\hline p3 & 1 & 0.9586 & $0 / 0414$ \\
\hline p4 & 1 & 0.9834 & 0.0166 \\
\hline p5 & 1 & 0.9878 & 0.0122 \\
\hline p6 & 1 & 1.0284 & -0.0284 \\
\hline p7 & 0 & 0.1491 & -0.1491 \\
\hline p8 & 1 & 0.7767 & 0.2233 \\
\hline p9 & 0 & 0.0024 & -0.0024 \\
\hline p10 & 0 & 0.0024 & -0.0024 \\
\hline p11 & 1 & 1.0611 & -0.0611 \\
\hline p12 & 1 & 1.0711 & -0.0711 \\
\hline P13 & 1 & 1.0711 & -0.0711 \\
\hline P14 & 1 & 0.9837 & 0.0163 \\
\hline P15 & 1 & 0.9990 & 0.0010 \\
\hline
\end{tabular}

c. Pola 3

- Jumlah neuron pada input layer sebanyak 7 neuron.

- Jumlah neuron pada hidden layer sebanyak 9 neuron.

- Toleransi error sebesar 0.01

- Learning rate sebesar 0.1

- Momentum sebesar 0.7

- Max epoch sebanyak 100.000 epoch

Pada proses pelatihan secara manual, didapatkan hasil berupa output dan juga error. Proses pelatihan dengan mengunakan syntax pada matlab yaitu dengan : net=train(net,pn,tn). Grafik dari Jaringan Syaraf Tiruan pola 4 dapat dilihat pada Gambar 3 berikut :

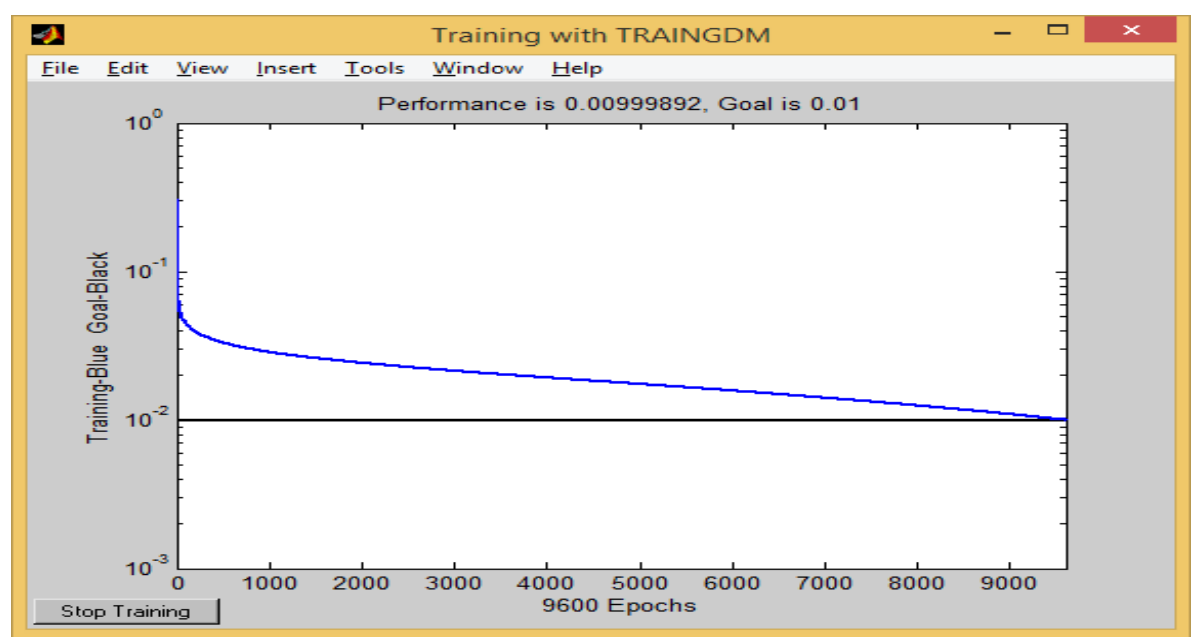

Gambar 3 Pelatihan Model Arsitektur 7-9-1 Mencapai Goal 
Dari gambar di atas dapat dilihat bahwa goal akan tercapai pada jumlah epoch ke 3702 dengan nilai error 0,00999963. Hasil dari pengujian Jaringan Saraf Tiruan setelah pelatihan dengan target error yang diinginkan adalah 0,01 dapat terlihat pada Tabel 6 di bawah ini :

Tabel 6 Hasil Pelatihan Jaringan Saraf Tiruan Dengan Model 7-9-1

\begin{tabular}{|c|c|c|c|}
\hline $\mathbf{P}$ & Target & Hasil & Error \\
\hline p1 & 1 & 0.9716 & 0.0284 \\
\hline p2 & 1 & 1.0168 & -0.0168 \\
\hline p3 & 1 & 0.9716 & 0.0284 \\
\hline p4 & 1 & 0.9762 & 0.0238 \\
\hline p5 & 1 & 1.0213 & -0.0213 \\
\hline p6 & 1 & 1.0518 & -0.0518 \\
\hline p7 & 0 & 0.1702 & -0.1702 \\
\hline p8 & 1 & 1.0209 & -0.0209 \\
\hline p9 & 0 & 0.0262 & -0.0262 \\
\hline p10 & 0 & 0.0262 & -0.0262 \\
\hline p11 & 1 & 0.9027 & 0.0973 \\
\hline p12 & 1 & 1.0471 & -0.0471 \\
\hline P13 & 1 & 1.0471 & -0.0471 \\
\hline P14 & 1 & 1.0494 & -0.0494 \\
\hline P15 & 1 & 1.0170 & -0.0170 \\
\hline
\end{tabular}

\subsection{Pengujian Data}

a.Dengan pola 1

Pengujian Jaringan Syaraf Tiruan dengan arsitektur 7-4-1, dapat dilihat dari Gambar 4 berikut :

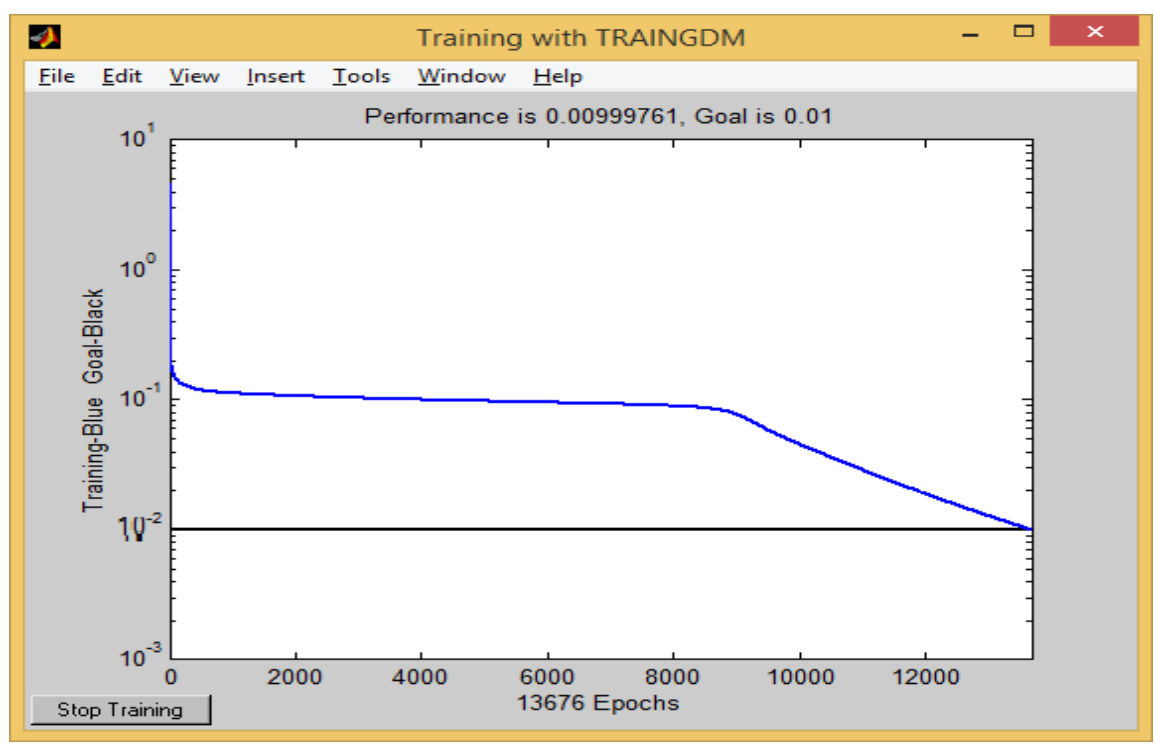

Gambar 4. Pengujian Model Arsitektur 7-4-1 Mencapai Goal 
Dari gambar di atas dapat dilihat bahwa goal akan tercapai pada jumlah epoch ke 13676 dengan nilai error 0,00999761. Pelatihan ini menggunakan Jaringan Saraf Tiruan dengan metode backpropagation dan mempunyai model arsitektur jaringan 7-4-1. Hasil dari pengujian Jaringan Saraf Tiruan setelah pengujian dengan target error yang diinginkan adalah 0,01 dapat terlihat pada tabel 7 di bawah ini :

\section{Tabel 7 Hasil Pengujian Jaringan Saraf Tiruan Dengan Model 7-4-1}

\begin{tabular}{|c|c|c|c|}
\hline $\mathbf{P}$ & Target & Hasil & Error \\
\hline p1 & 1 & 1.0215 & -0.0215 \\
\hline p2 & 1 & 0.9995 & 0.0005 \\
\hline p3 & 0 & -0.0621 & 0.0621 \\
\hline p4 & 1 & 1.0106 & -0.0106 \\
\hline p5 & 1 & 0.9995 & 0.0005 \\
\hline p6 & 1 & 1.0250 & -0.0250 \\
\hline p7 & 1 & 1.0215 & -0.0215 \\
\hline p8 & 1 & 0.8105 & 0.1895 \\
\hline p9 & 0 & 0.1766 & -0.1766 \\
\hline p10 & 1 & 1.0675 & -0.0675 \\
\hline P11 & 0 & -0.1058 & 0.1058 \\
\hline P12 & 0 & 0.1497 & -0.1497 \\
\hline P13 & 1 & 1.0215 & -0.0215 \\
\hline P14 & 1 & 1.0535 & -0.0535 \\
\hline P15 & 1 & 0.8105 & 0.1895 \\
\hline & & & \\
\hline
\end{tabular}

b. Dengan pola 2

Pengujian Jaringan Syaraf Tiruan dengan arsitektur 7-5-1, dapat dilihat dari Gambar 5 berikut :

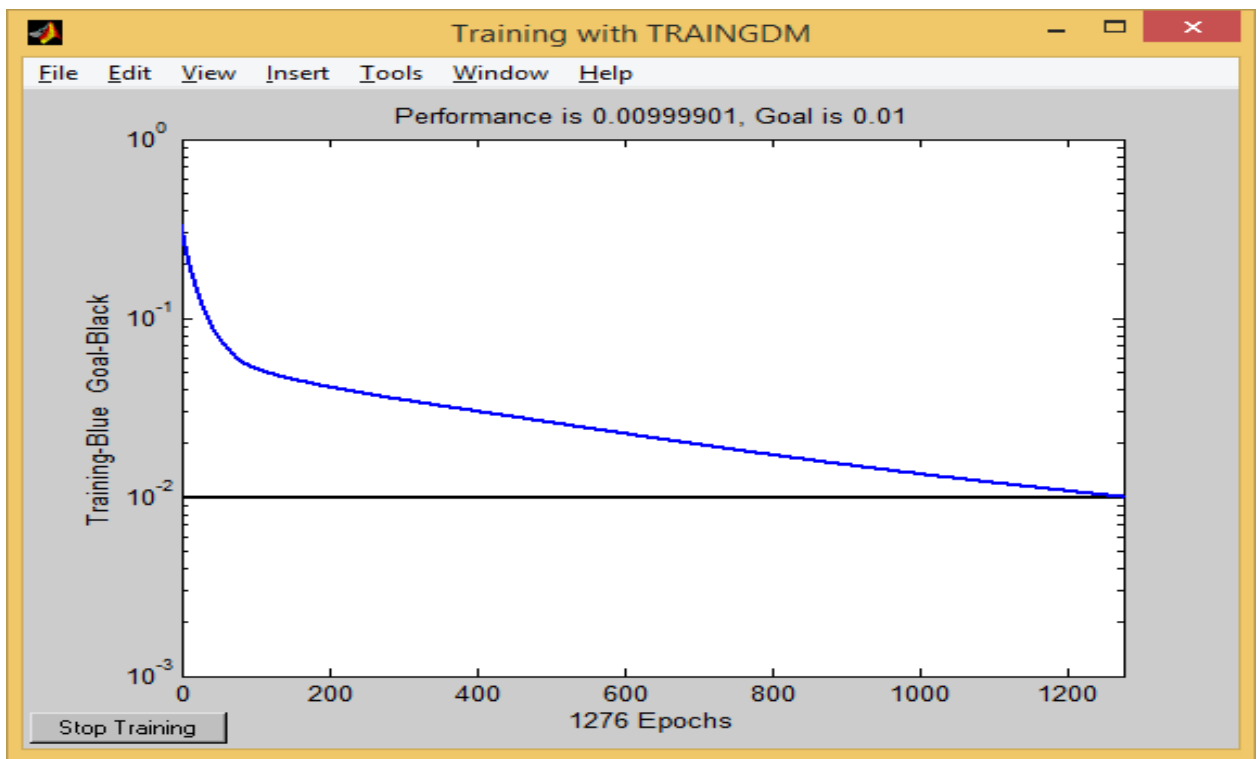

Gambar 5. Pengujian Model Arsitektur 7-5-1 Mencapai Goal 
Dari gambar di atas dapat dilihat bahwa goal akan tercapai pada jumlah epoch ke 1276 dengan nilai error 0,00999901. Pelatihan ini menggunakan Jaringan Saraf Tiruan dengan metode backpropagation dan mempunyai model arsitektur jaringan 7-4-1. Hasil dari pengujian Jaringan Saraf Tiruan setelah pengujian dengan target error yang diinginkan adalah 0,01 dapat terlihat pada Tabel 8 di bawah ini :

Tabel 8 Hasil Pengujian Jaringan Saraf Tiruan Dengan Model 7-5-1

\begin{tabular}{|c|c|c|c|}
\hline P & Target & Hasil & Error \\
\hline p1 & 1 & 1.0095 & -0.0095 \\
\hline p2 & 1 & 0.8265 & 0.1735 \\
\hline p3 & 0 & 0.1117 & -0.1117 \\
\hline p4 & 1 & 0.9289 & 0.0711 \\
\hline p5 & 1 & 0.8265 & 0.1735 \\
\hline p6 & 1 & 1.0053 & -0.0053 \\
\hline p7 & 1 & 1.0095 & -0.0095 \\
\hline p8 & 1 & 1.0320 & -0.0320 \\
\hline p9 & 0 & 0.2073 & -0.2073 \\
\hline p10 & 1 & 1.1162 & -0.1162 \\
\hline P11 & 0 & 0.0076 & -0.0076 \\
\hline P12 & 0 & -0.1137 & 0.1137 \\
\hline P13 & 1 & 1.0095 & -0.0095 \\
\hline P14 & 1 & 1.0214 & -0.0214 \\
\hline P15 & 1 & 1.0320 & -0.0320 \\
\hline
\end{tabular}

c. Dengan Model Arsitektur 7-9-1

Pengujian Jaringan Syaraf Tiruan dengan arsitektur 7-9-1, dapat dilihat dari Gambar 6 berikut :

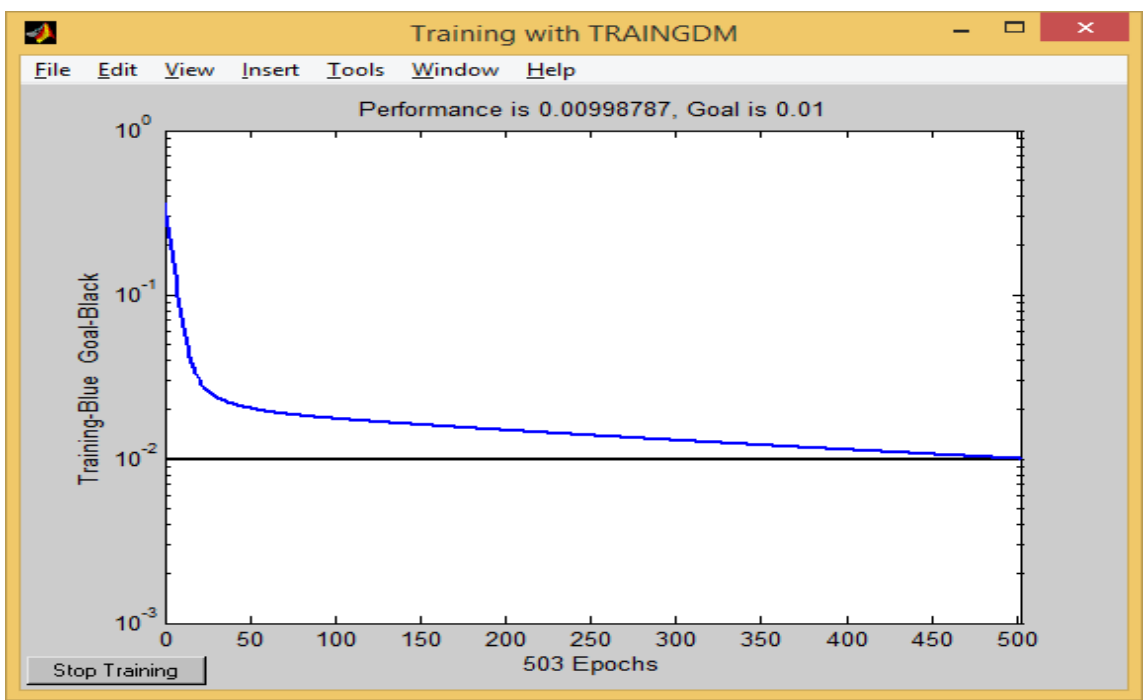

Gambar 6. Pengujian Model Arsitektur 7-9-1 Mencapai Goal 
Dari gambar di atas dapat dilihat bahwa goal akan tercapai pada jumlah epoch ke 503 dengan nilai error 0,0099878. Pelatihan ini menggunakan Jaringan Saraf Tiruan dengan metode backpropagation dan mempunyai model arsitektur jaringan 7-9-1. Hasil dari pengujian Jaringan Saraf Tiruan setelah pengujian dengan target error yang diinginkan adalah 0,01 dapat terlihat pada tabel 9 di bawah ini :

Tabel 9 Hasil Pengujian Jaringan Saraf Tiruan Dengan Model 7-4-1

\begin{tabular}{|c|c|c|c|}
\hline $\mathbf{P}$ & Target & Hasil & Error \\
\hline p1 & 1 & 1.0023 & -0.0023 \\
\hline p2 & 1 & 0.8783 & 0.1217 \\
\hline p3 & 0 & -0.1887 & 0.1887 \\
\hline p4 & 1 & 0.9523 & 0.0477 \\
\hline p5 & 1 & 0.8783 & 0.1217 \\
\hline p6 & 1 & 0.9589 & 0.0411 \\
\hline p7 & 1 & 1.0023 & -0.0023 \\
\hline p8 & 1 & 0.9798 & 0.0202 \\
\hline p9 & 0 & 0.1169 & -0.1169 \\
\hline p10 & 1 & 1.1086 & -0.1086 \\
\hline P11 & 0 & 0.0204 & -0.0204 \\
\hline P12 & 0 & 0.2238 & -02238 \\
\hline P13 & 1 & 1.0023 & -0.0023 \\
\hline P14 & 1 & 1.0616 & -0.0616 \\
\hline P15 & 1 & 0.9798 & 0.0202 \\
\hline
\end{tabular}

\subsection{Perbandingan Hasil dari ke tiga pola}

Hasil perbandingan ke tiga pola yang telah dilatih dan diuji dapat dilihat pada Tabel 10 dan Tabel 11 berikut ini :

Tabel 10 Hasil Perbandingan Pola Akurasi Data Pelatihan

\begin{tabular}{|c|c|c|c|}
\hline & $7-4-1$ & $7-5-1$ & $7-9-1$ \\
\hline Epochs & $\mathbf{0 , 0 0 9 9 9 3 2 6}$ & $\mathbf{0 , 0 0 9 9 9 8 2 7}$ & $\mathbf{0 , 0 0 9 9 9 9 6 3}$ \\
\hline MSE & 2776 & 3835 & 3702 \\
\hline Akurasi & $\mathbf{9 9 , 9 9 9 6 9}$ & $\mathbf{9 9 , 9 9 4 9}$ & 100 \\
\hline MAPE & $\mathbf{0 , 0 1 0 7 1}$ & $\mathbf{0 , 0 1 7 8 6}$ & $\mathbf{0}$ \\
\hline
\end{tabular}

Tabel 11 Hasil Perbandingan Pola Akurasi Data Pengujian

\begin{tabular}{|c|c|c|c|}
\hline & $7-4-1$ & $7-5-1$ & $7-9-1$ \\
\hline Epochs & $\mathbf{0 , 0 0 9 9 8 6 7 1}$ & $\mathbf{0 , 0 0 9 9 8 9 9 7}$ & $\mathbf{0 , 0 0 9 9 7 6 5 4}$ \\
\hline
\end{tabular}




\begin{tabular}{|c|c|c|c|}
\hline MSE & $\mathbf{2 5 2 1}$ & $\mathbf{1 0 2 7}$ & $\mathbf{2 8 2}$ \\
\hline Akurasi & 99,9994 & 100,002 & 100 \\
\hline MAPE & 0,00061 & $-0,00182$ & 0 \\
\hline
\end{tabular}

Dari tabel di atas, dapat disimpulkan pola jaringan syaraf tiruan 7-9-1 merupakan pola yang terbaik, karena dari hasil pelatihan dan pengujian memiliki Nilai MAPE (Mean Absolute Percentage Error) yang didapatkan adalah sebesar 0. Kemudian tingkat akurasi dari proses pelatihan dan pengujian ini menjadi $100 \%$.

\section{Kesimpulan}

Dari 15 target data pengujian yang digunakan pada pola 7-9-1, dapat dilihat bahwa nilai yang tidak sesuai target hanya 4 orang. Itu berarti bahwa dari 15 mahasiswa yang tugas akhirnya dilakukan penilaian kelayakan, 4 orang yang tidak sesuai standard dan panduan penulisan tugas akhir. Kesimpulan dari penelitian ini adalah tugas akhir mahasiswa AMIK Bukittinggi, hanya $26 \%$ yang tidak sesuai panduan penulisan dan sisanya $74 \%$ sesuai dengan standard dan panduan yang telah ditetapkan perguruan tinggi.

\section{Daftar pustaka}

[1] Indira, B. et.al. "Classification and Recognition of Printed Hindi Characters Using Artificial Neural Networks". MECS. 2012; vol 6: 15-21.

[2] Barman, Debaditya dan Nirmalya Chowdhury ."A Method of Movie Business Prediction Using Back-propagation Neural Network". MECS. (2012); vol 11: 67-73.

[3] Dwi Lestari, Yuyun. "Jaringan Syaraf Tiruan Untuk Prediksi Penjualan Jamur Menggunakan Algoritma BackPropagation” Jurnal ISD (2017) Vol. 2 No. 1

[4] Kosasi, Sandi. "Penerapan Metode Jaringan Syaraf Tiruan BackPropagation Untuk Memprediksi Nilai Ujian Sekolah”. Jurnal teknologi (2014) Vol. 7 No. 1.

[5] Mansour, AbdelMajid Hassan dkk. "Voice recognition Using back propagation algorithm in neural networks" International Journal of Computer Trends and Technology (IJCTT) 2015 Vol. 23 No. 3

[6] M.Subhasree dan C.Arun Priya. "Forecasting Vegetable Price Using Time Series Data" International Journal of Advanced Research (2016), Volume 3

[7] Sudarsono, Aji. "Jaringan Syaraf Tiruan Untuk Memprediksi Laju Pertumbuhan Penduduk Menggunakan Metode BackPropagation "Jurnal Media Infotama (2016). Vol. 12 No.1.

[8] Suresh, Abhijit. dkk. "Particle swarm optimization over back propagation neural network for length of stay prediction" International Conference on Information and Communication Technologies (2014)

[9] Triyono, Andri dkk. "Penerapan Metode Jaringan Syaraf Tiruan Backpropagation Untuk Meramalkan Harga Saham (IHSG)" Jurnal Sistem dan Informatika (2016). Vol. $11 \mathrm{No}$.

[10] Widodo, Wahyu dkk. "Jaringan Syaraf Tiruan Prediksi Penyakit Demam Berdarah Dengan Menggunakan Metode BackPropagation” Jurnal ITATS (2014) Vol. 18 No. 1 